\title{
Ranging behaviour and reproductive rate in the threatened population of roe deer in Gargano, South Italy
}

\author{
V. AIELLO, S. LOVARI^, \& A. BOCCI \\ University of Siena, Dept. of Life Sciences, Research Unit of Behavioural Ecology, Ethology and Wildlife Management, \\ Siena, Italy
}

(Received 8 November 2012; accepted 15 fuly 2013)

\begin{abstract}
The ranging behaviour of Italian roe deer Capreolus capreolus italicus was studied for 2 years in a low density, "vulnerable" population (ca. 6 ind./100 ha), in an Apennine-continental forest of Southern Italy (Gargano National Park), through satellite radiotracking. The seasonal median home range size of does ranged significantly between 16 ha, in spring, and $43 \mathrm{ha}$, in the cold months. Monthly home range size of does did not change significantly in daylight, night and twilight. The reproductive success (fawns:female) of our radiotagged does was very low (0.8-1.3 vs the expected 2) in both years of study, contrasting with the normal productivity of roe does, especially when density is low.
\end{abstract}

Keywords: Capreolus capreolus, ranging movements, reproductive success

\section{Introduction}

Two subspecies of roe deer Capreolus capreolus (L., 1758) (Mammalia: Cervidae) are present in Italy: the north-central European one, C. c. capreolus, and the southern lineage, C. c. italicus (Lorenzini et al. 2002; Randi et al. 2004; Lorenzini \& Lovari 2006). The presence of the latter (Italian roe deer) is mostly limited to southern Tuscany (ca. 10,000 ind., Carnevali et al. 2009), while three small, disjoint subpopulations are in Castelporziano Reserve (Rome; ca. 200 ind., Carnevali et al. 2009), Orsomarso mountains (reliable data on numbers not available) and Gargano National Park (cf. Study area).

Features of the population of roe deer in Gargano are unknown. It has been isolated for centuries (Perco \& Calò 1994), because of the surrounding wetlands (drained between the nineteenth and twentieth centuries) and steppe: unsuitable habitats for roe deer (Linnell et al. 1998a), separating the Gargano headland from the mainland. The effects of genetic drift, lack of gene flow (Perco \& Calò 1994) and long persistence at low numbers (Tassi 1969; Perco 1985; Apollonio \& Trocchi 1988) are reflected in the low level of expected proportions of heterozygotes and in the small mean number of alleles per locus (Lorenzini et al. 2002). Poaching, free-ranging dogs and competition with livestock left in the wild are the other main threats for this "vulnerable" population (e.g. Focardi et al. 2009). Information on roe deer numbers is scanty: Tassi (1969) reported ca. 100 individuals; Perco (1985) described this herd as one on the brink of extinction (40-100 ind.); Apollonio and Trocchi (1988) assessed a minimum distribution area of 5289 ha, with very few individuals left. Official drive counts have been carried out by the University of Siena, in cooperation with park personnel, since 2004 (cf. Study area).

Research on spatial behaviour is of primary importance when wildlife management is concerned, especially with conservation of threatened taxa (Bookhout 1996). In roe deer, home range size is strictly related to density (being greater at lower densities; Vincent et al. 1995; Kjellander et al. 2004; Saïd \& Servanty 2005), varying in relation to the level of feeding competition in females, and to the competition for mating in males (Kjellander et al. 2004). Males usually show larger ranges than females (Kjellander et al. 2004)

*Correspondence: S. Lovari, University of Siena, Dept. of Life Sciences, Research Unit of Behavioural Ecology, Ethology and Wildlife Management, via PA Mattioli 4, 53100 Siena, Italy. Tel: +39 0577 233501. Fax: +390577 233515. Email: lovari@unisi.it 
and winter ranges are larger than summer ranges (Kjellander et al. 2004; Saïd et al. 2009). Very little information is available on the spatial behaviour of the Italian subspecies of roe deer (e.g. San José \& Lovari 1998; Melis et al. 2005; Lovari et al. 2008a).

In this study, we have aimed to describe the spatial behaviour of radiotagged Italian roe deer from the threatened, low-density population of Gargano National Park, with particular reference to does.

\section{Study area}

Our research has been carried out in the Foresta Umbra, Gargano National Park (Puglia Region, Italy; $\left.15.83^{\circ} \mathrm{E}, 41.81^{\circ} \mathrm{N} ; 118,144 \mathrm{ha}\right)$. The study area covers 11,070 ha, at an altitude ranging between $150 \mathrm{~m}$ and $830 \mathrm{~m}$ above sea level, and includes three zones: the upper one, represented by extensive forest patches dominated by beech Fagus sylvatica; the intermediate one, covered by oaks Quercus cerris and other Quercus spp; and the lower one, covered with Mediterranean macchia. Ferns are widespread in clearings, probably as a result of livestock overgrazing (Archer \& Smeins 1991), and set a barrier for tree regeneration (Cohen et al. 1995; Walker \& Boneta 1995), being at the same time unpalatable for roe deer (Lovari et al. 2008b).

The climate is Apennine-continental, with mean winter temperatures between 8 and $11^{\circ} \mathrm{C}$ in January, and mild summers (mean temperature up to $21^{\circ} \mathrm{C}$, in July-August; Macchia et al. 2000). Precipitation is greater in winter $(169.5 \mathrm{~mm})$ than in summer (128.4 mm).

Official counts (2004 and 2005: Lovari et al. 2005; 2008: Lovari et al. 2008b; 2009: Lovari et al. 2009) estimated a maximum density of ca. 6.5 ind./100 ha over an area of 11,000 ha, with a sex ratio strongly biased toward females (2004: 1:1.8; 2005: 1:1.2; 2006: 1:1.9; 2007: 1:1.4, respectively). This estimate should not be extended to all the Forest Umbra, as potential constraints, e.g. the very low density of roe deer, led to select biased count areas, small areas where this cervid was known to occur (percentage of censused forest: $6.5 \%, 5.5 \%, 3.5 \%$, $1.4 \%$, respectively).

Stray dogs, red foxes and, according to local information, perhaps wild boar were potential predators of fawns in our study area. Livestock (cattle, goats) was present - although illegally. No disease outbreak has been recorded in wild or domestic ruminants in our study area and in its neighbourhood; in fact, Focardi et al. (2009) did not mention disease as one of the main threats for this population of roe deer.

\section{Materials and methods}

Eight adult (i.e. $\geq 2$ years old, females; $\geq 3$ years old, males) roe deer (does: $\mathrm{N}=6$; bucks: $\mathrm{N}=2$ ) were caught with nets during drive beating sessions (Jones 1984) in autumn (Oct. 2008) and spring (Mar. 2009), aged through tooth eruption and wear, and fitted with global positioning system (GPS) Pro-Light-1 radio-collars (Vectronic Aerospace $\mathrm{GmbH}^{\circledR}$ ), transmitting on $150-151 \mathrm{MHz}$ [very high frequency (VHF) transmitter]. Roe deer were tracked from Oct. 2008 to Aug. 2010 and fixes collected every 11 hours, from October to May. Radiolocations were downloaded through the software GPS Plus Collar Manager (Vectronic Aerospace $\mathrm{GmbH}^{\circledR}$ ). A mean number of 73.2 fixes $(\mathrm{SD}=39.9)$ /individual were monthly collected.

Radiotracking data were analysed using the software Animal Movement v. 2.0 beta for ArcView 3.2 (Hooge \& Eichenlaub 1997). Home range (hereafter HR) features were seasonally and monthly assessed through the fixed $90 \%$ kernel method (Worton 1989), using Least Square Cross Validation (LSCV) criterion. When fixes showed a bimodal distribution (i.e. a deer used two distinct areas in the same period), assessed through the Dip test (Hartigan \& Hartigan 1985), the two sub-HRs were calculated separately to avoid shortcomings of the method, i.e. an artificial increase of size of each sub-HR.

Seasonal movements have been defined on the basis of the percentage overlap of home ranges (e.g. Sabine et al. 2002; Berger 2004; Hebblewhite et al. 2006), through the Minta Index (Minta 1992). Seasons were considered as Winter, Dec.-Feb.; Spring, Mar.-May; Summer, Jun.-Aug.; Autumn, Sep.-Nov.

The mobility was assessed as the interfix distance, i.e. the distance measured in meters between one localization and the following one.

Virtually all the summer mortality of roe deer fawns occurs within the first few weeks of life (Linnell et al. 1998b; Gaillard et al. 2000). As the thick vegetation and morphology of the study area prevented any direct assessment in the period immediately after birth, we recorded the reproductive success of does as presence of fawns at heel, in summer, after the hiding phase (but before weaning). The VHF transmitters were used to approach (homing in) radiocollared does to assess the presence and the number of kids at heel (reproductive success at the net of neonatal mortality). This assessment was carried out monthly (June, July and August) to decrease the possibility of missing fawns.

Medians (hereafter, $M$ ) have been used in all our analyses as they do not require a normal 
distribution of data. Statistical analysis were carried out through SPSS 12.0 for Windows. All tests were non-parametric, two-tailed (Siegel \& Castellan 1988). All p-values were considered significant at a level of 0.05 .

\section{Results}

The reproductive success of does was low in both years of study: apparently more than $65 \%$ of our radiotagged deer had just one fawn (Table I), instead of twins or triplets.

All our radiotagged does behaved as resident individuals, i.e. remaining in the same area all year long and showing a great overlap between summer and winter ranges $(M=56 \%, Q 1=53 \%, Q 3=71 \%)$. The same pattern was also found for males $(\mathrm{N}=2$; $\mathrm{M}=43 \%, \mathrm{Q} 1=28 \%, \mathrm{Q} 3=58 \%$ ).

As to other features of spatial behaviour, yearly data were pooled together, if no significant difference was found between years in the HR size of the same season (Wilcoxon's matched pairs test: $\mathrm{Z}=0.169-1.260, \mathrm{p}>0.05, \mathrm{~N}=6-8)$ and in the interfix distance of the same month (Wilcoxon's matched pairs test: $Z=0.135-1.690, p>0.05$, $\mathrm{N}=6-8$ ).

Amongst does, the seasonal median HR size varied from 16 to 43 ha (Figure 1), being greater in autumn and winter, while decreasing significantly in spring (Wilcoxon's matched pairs test: $Z=2.599$, $\mathrm{p}=0.009, \mathrm{~N}=10$ ). Our small sample of males showed a similar pattern, with seasonal HRs varying between 15 ha (in summer) and 47 ha (in winter).

Monthly home range sizes of does did not change in daylight, at night and at twilight (Kruskal-Wallis test: $\mathrm{H}=0.012-2.572, \mathrm{p}>0.05, \mathrm{~N}=6)$.

The monthly mobility of does (Figure 2) significantly decreased in spring (Wilcoxon's matched pairs

Table I. Reproductive success of roe deer does, assessed as presence of fawns at heel in summer (Jun.-Aug.).

\begin{tabular}{lcc}
\hline Animal ID & Year & No. of fawns \\
\hline F1 & 2009 & 2 \\
& 2010 & 2 \\
F3 & 2009 & 1 \\
& 2010 & 1 \\
F4 & 2009 & 2 \\
& 2010 & 0 \\
F5 & 2009 & 1 \\
& 2010 & 1 \\
F6 & 2009 & 1 \\
& 2010 & 1 \\
F7 & 2009 & 1 \\
& 2010 & 1 \\
\hline
\end{tabular}

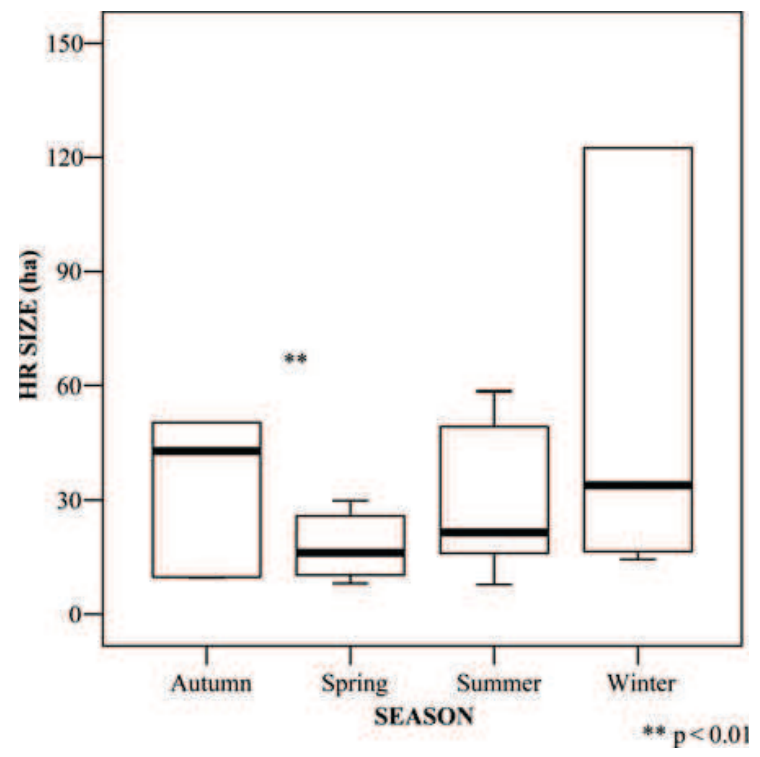

Figure 1. Seasonal home range (HR) size (ha) of our radiotagged does $(N=6$; bold lines representing median values; rectangles representing quartiles; bars representing ranges), in Foresta Umbra in 2009-2010.

test: cf. March-April, $\mathrm{Z}=3.059, \mathrm{p}=0.002, \mathrm{~N}=12$; cf. April-May, $\mathrm{Z}=2.432, \mathrm{p}=0.015, \mathrm{~N}=12$ ) and then gradually increased during the summer/autumn months. This pattern strongly contrasts with the consistent mobility $\left(M=218.53 \mathrm{~m}, \mathrm{Q}_{1}=199.29 \mathrm{~m}\right.$, $\mathrm{Q}_{3}=237.02 \mathrm{~m}$ ) of our sample of males throughout the year, but for a mild increase in January $\left(\mathrm{M}=324.12 \mathrm{~m}, \mathrm{Q}_{1}=277.63 \mathrm{~m}, \mathrm{Q}_{3}=291.76 \mathrm{~m}\right)$ and February $\left(M=306.13 \mathrm{~m}, \mathrm{Q}_{1}=220.85 \mathrm{~m}\right.$, $\left.\mathrm{Q}_{3}=368.78 \mathrm{~m}\right)$.

\section{Discussion}

Spatial behaviour (e.g. home range size and mobility) is the result of a combination of phenotypic plasticity and natural selection that reflects successful strategies to maximise individual fitness (Rettie \& Messier 2001). In roe deer, home range size depends mostly on the abundance of food resources to optimise fitness (Tufto et al. 1996), decreasing with the increase of vegetation biomass (Saïd et al. 2005), as well as on sociality (Andersen et al. 1998). Especially in summer, when males are territorial (Andersen et al. 1998), the home range size of roe deer is strongly influenced by resource availability because of constraints on reproduction (Tufto et al. 1996). In our radiotagged population of does, home range size as well as mobility decreased in spring and then started increasing again in summer, probably in response to changes both in vegetation biomass and quality (Cederlund 1983; Tufto et al. 1996; Cimino \& Lovari 


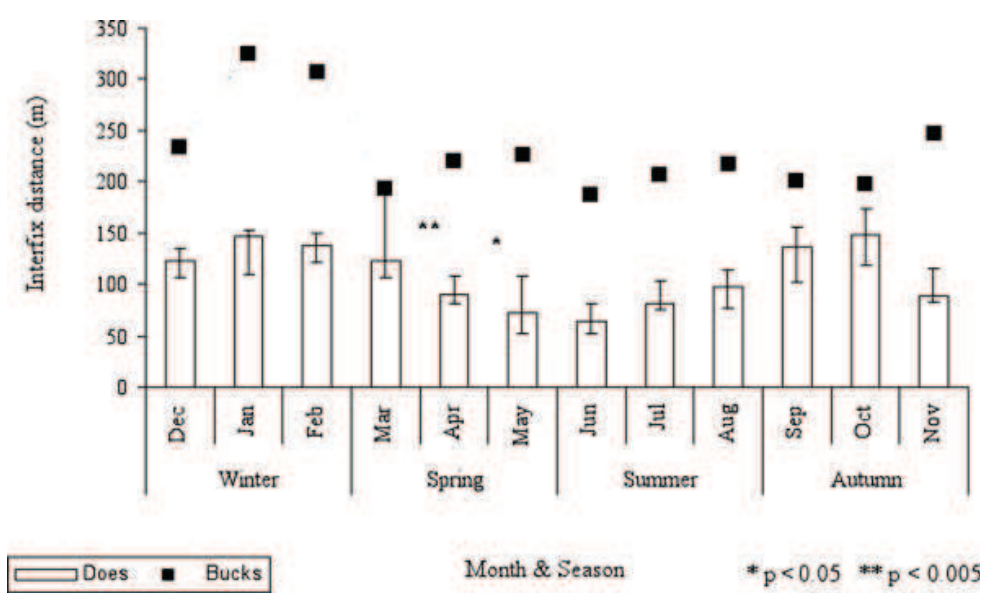

Figure 2. Monthly interfix distance (i.e. mobility; rectangles representing medians; bars representing quartiles) of radiotagged does, dotted line representing mobility trend in males, in Foresta Umbra in 2009-2010.

2003; Saïd et al. 2005), and to reproductive constraints (Tufto et al. 1996; San José \& Lovari 1998). In this respect, mobility was greater in April, when does have no offspring at heel, than in May-June, the birth period. In July and August, interfix distance increases, probably because of increased fawn mobility (Linnell et al. 1998b; San José \& Lovari 1998) and doe searching behaviour for a mate (Andersen et al. 1995; Liberg et al. 1998; Lovari et al. 2008a; Richard et al. 2008). As to seasonal home range size and movement pattern, they did not differ from what has been found in other resident populations of roe deer (European ssp: Kjellander et al. 2004; Lamberti et al. 2004; Saïd \& Servanty 2004; Saïd et al. 2009; Italian ssp: Lovari \& San José 1997; Melis et al. 2005). Conversely, our small sample of males showed a very consistent pattern of mobility throughout the spring and the summer months, when bucks are territorial. Territories are in fact established by adult males in spring and maintained over the rutting season, in July and August (Liberg et al. 1998).

The reproductive success of our radiotagged does (fawns:female) was low in both years (0.8-1.3; Table I), contrasting with the normal productivity of roe deer does (European ssp: 2.04-2.44, Andersen \& Linnel 2000; 1.3-1.4, Saïd et al. 2005; 1.75, Macdonald \& Johnson 2008; Italian ssp: productivity of the Italian roe deer does not seem to differ from that of the European subspecies, own data), especially when density is low (Vincent et al. 1995), as in our population. In roe deer, body fat reserves are poor (Hewison et al. 1996), compared to the other temperate and northern cervids (Holland 1990), with important effects when the energy expenditure is at its maximum (i.e. in does, in the last two months of pregnancy and in the first month of lactation;
Mauget et al. 1997). Therefore, does allocate high levels of resources to reproduction compared to most other ungulates (Hewison et al. 1996; Andersen et al. 1998) and the survival of fawns is strongly affected by environmental variation, probably through the effects on maternal nutrition (Gaillard et al. 1998). When food supply is poor in late spring and early summer, females reduce lactation, which is energetically expensive, and summer survival of fawns decreases (Sempéré et al. 1998). Furthermore, litter size (as well as winter weight of fawns and birthdate) is affected by the quality of the doe's winter home range (Nilsen et al. 2004). In our study area, the homogeneous forested habitat, with scarce underwood and rare, fern-infested clearings, provides a poor food supply during the whole year, most likely influencing the reproductive rate of does. The importance of the loss of genetic variability on fertility of this population is unknown. Other factors which may determine early mortality of roe deer fawns are predation (the primary cause of first summer mortality in areas where predators occur, Linnell et al. 1995; Jarnemo 2002), weather conditions (i.e. cold and wet) in the post-birth period (Wotschikowsky \& Schwab 1994) and road kills (Andersen et al. 1995). In our study area, no hair of roe deer was found in faeces of wild boar (I. Minder, unpublished data), in May-June, i.e. the deer birth season, but we cannot rule out predation by stray dogs and red foxes on fawns.

Annual recruitment is a key factor to preserve and/or increase a population (e.g. Caughley 1977). The low fawns-to-female ratio we detected in the vulnerable population of Gargano is a source of concern for the preservation of this roe deer herd, if confirmed. An effort should be made to look at this parameter in further studies. Inbreeding depression 
of this long-time isolated population, or disease temporarily affecting this herd (not confirmed during our study), or simply an adaptation to the low local habitat productivity (the Foresta Umbra is mainly composed of beech forest, an unsuitable type of forest for roe deer) could all be factors responsible for the low rate of population increase.

\section{Acknowledgements}

We are greatly indebted to M. Caldarella, O. Cilenti, L. Cimino, L. De Lullo, O. Di Miscia, M. Gioiosa, M. Marrese, S. Mattioli, S. Nicoloso and A. Petrella as well as to all the other collaborators (Dimensione Ricerca Ecologia Ambiente - Pratovecchio, AR students, volunteers, forest wardens and staff of the Gargano National Park) for their help in netting operations. A. Meriggi and two anonymous reviewers provided useful suggestions to improve our paper. We are grateful to S. Angeloro and to the Italian Air Force for providing practical facilities. F. Tanzarella, C. Strizzi and A. Perna provided backing and encouragement throughout all our work. Financial support was provided by the Gargano National Park Agency to SL.

\section{References}

Andersen R, Duncan P, Linnell JDC. 1998. The European roe deer: The biology of success. Oslo, Norway: Scandinavian University Press.

Andersen R, Linnell J. 2000. Irruptive potential in roe deer: Density-dependent effects on body mass and fertility. Journal of Wildlife Management 64:698-706.

Andersen R, Linnell J, Aenes R. 1995. Rådyr I kulturalandskapet. Sluttrapport. NINA Fagrapport 10:1-80.

Apollonio M, Trocchi V. 1988. La popolazione di capriolo (Capreolus capreolus) del Gargano: Distribuzione e prospettive di conservazione. In: Spagnesi $M$, Toso $S$, editors. Atti I Convegno Nazionale dei Biologi della Selvaggina Supplemento Ricerche Biologia della Selvaggina, 14. Savignano sul Panaro (Modena), Italia: Tipolitografia FG. pp. 595-596.

Archer S, Smeins FE. 1991. Ecosystem-level processes. In: Heitschmidt RK, Stuth JW, editors. Grazing management: An ecological perspective. Portland, Oregon: Timber Press. pp. 109-139.

Berger J. 2004. The last mile: How to sustain long-distance migration in mammals. Conservation Biology 18:320-331.

Bookhout TA, editor. 1996. Research and management techniques for wildlife and habitats. Bethesda, MD: The Wildlife Society.

Carnevali L, Pedrotti L, Riga F, Toso S. 2009. Banca dati Ungulati: Status, distribuzione, consistenza, gestione e prelievo venatorio delle popolazioni di Ungulati in Italia. Biologia e Conservazione della Fauna (ISPRA) 117:1-161.

Caughley G. 1977. Analysis of vertebrate populations. London: John Wiley \& Sons.
Cederlund G. 1983. Home range dynamics and habitat selection by roe deer in a boreal area in central Sweden. Acta Theriologica 28:443-460.

Cimino L, Lovari S. 2003. The effects of food or cover removal on spacing patterns and habitat use in roe deer (Capreolus capreolus). Journal of Zoology 261:299-305.

Cohen AL, Singhakumara BMP, Ashton PMS. 1995. Releasing rain forest succession: A case study in the Dicranopterislinearis fernlands of Sri Lanka. Restoration Ecology 3:261-270.

Focardi S, Montanaro P, La Morgia V, Riga F. 2009. Piano d'azione nazionale per il Capriolo italico (Capreolus capreolus italicus). Quaderni di Conservazione della Natura 31. Roma: Ministero Ambiente - ISPRA.

Gaillard JM, Festa-Bianchet M, Yoccoz NG, Loison A, Toigo C. 2000. Temporal variation in fitness components and population dynamics of large herbivores. Annual Review of Ecology, Evolution and Systematics 31:367-393.

Gaillard JM, Liberg O, Andersen R, Hewison AMJ. 1998. Population dynamics of roe deer. In: Andersen R, Duncan P, Linnell JDC, editors. The European roe deer: The biology of success. Oslo, Norway: Scandinavian University Press. pp. 309-336.

Hartigan JA, Hartigan PM. 1985. The Dip Test of unimodality. The Annals of Statistics 13:70-84.

Hebblewhite M, Merrill EH, Morgantini LE, White CA, Allen JR, Bruns E, Thrston L, Hurd TE. 2006. Is the migratory behaviour of montane elk herds in peril? The case of Alberta's Ya Ha Tinda elk herd. Wildlife Society Bulletin 34:1280-1294.

Hewison AJM, Angibault JM, Bideau E, Vincent JP, Boutin J Sempéré A. 1996. Annual variation in body composition of roe deer (Capreolus capreolus) in moderate environmental conditions. Canadian Journal of Zoology 74:245-253.

Holland Ø. 1990. Body reserves and winter survival in roe deer. Transactions of the XIXth International Union of Game Biologists Congress. Trondheim: 187-191.

Hooge PN, Eichenlaub B. 1997. Animal movement extension to ArcView, ver. 1.2. Anchorage, AK: Alaska Biological Science Center, US Geological Survey.

Kjellander P, Hewison AJM, Liberg O, Angibault JM, Bideau E, Cargnelutti B. 2004. Experimental evidence for densitydependence of home-range size in roe deer (Capreolus capreolus L.): A comparison of two long-term studies. Behavioural Ecology 139:478-485.

Jarnemo A. 2002. Roe deer Capreolus capreolus fawns and mowing - Mortality rates and countermeasures. Wildlife Biology 8:211-218.

Jones DM. 1984. Physical and chemical methods of capturing deer. Veterinary Record 114:109-112.

Lamberti P, Mauri L, Apollonio M. 2004. Two distinct patterns of spatial behaviour of female roe deer (Capreolus caporeolus) in a monutainous habitat. Ethology, Ecology and Evolution 16:41-53.

Liberg O, Johansson A, Andersen R, Linnell JDC. 1998. Mating system, mating tactics and the function of male territoriality in roe deer. In: Andersen R, Duncan P, Linnell JDC, editors. The European roe deer: The biology of success. Oslo, Norway: Scandinavian University Press. pp. 221-256.

Linnell JDC, Aanes R, Andersen R. 1995. Who killed Bambi? The role of predation in the neonatal mortality of temperate ungulates. Wildlife Biology 1:209-224.

Linnell JDC, Duncan P, Andersen R. 1998a. The European roe deer: A portrait of a successful species. In: Andersen R, Duncan P, Linnell JDC, editors. The European roe deer: The biology of success. Oslo (Norway): Scandinavian University Press. pp. 11-22. 
Linnell JDC, Wahlström K, Gaillard JM. 1998b. From birth to independence: Birth, growth, neonatal mortality, hiding behaviour and dispersal. In: Andersen R, Duncan P, Linnell JDC, editors. The European roe deer: The biology of success. Oslo (Norway): Scandinavian University Press. pp. 257-283.

Lorenzini R, Lovari S. 2006. Genetic diversity and phylogeography of the European roe deer: The refuge area theory revisited. Biological Journal of the Linnean Society $88: 85-100$.

Lorenzini R, Lovari S, Masseti M. 2002. The rediscovery of the Italian roe deer: Genetic differentiation and management implications. Italian Journal of Zoology 69:367-379.

Lovari S, Bartolommei P, Meschi F, Pezzo F. 2008a. Going out to mate: Excursion behaviour of female roe deer. Ethology 114:886-896.

Lovari S, Bocci A, Caldarella M, Cimino L, Frassanito A, Gioiosa M, Lorenzini R, Mari F, Mattioli S, Minder I, Petrella A. 2008b. Conservazione della popolazione di capriolo italico nel Parco Nazionale del Gargano. Technical Report. Monte S. Angelo, FG: Gargano National Park.

Lovari S, Bocci A, Cimino L, Minder I. 2009. Monitoraggio della popolazione di capriolo italico nel Parco Nazionale del Gargano. Technical Report. Monte S. Angelo, FG: Gargano National Park.

Lovari S, Gioiosa M, Cimino L, Mattioli S, Plantamura G. 2005. Riqualificazione ambientale finalizzata al ripopolamento del capriolo Capreolus capreolus nel Parco Nazionale del Gargano. Technical Report. Monte S. Angelo, FG: Gargano National Park.

Lovari S, San José C. 1997. Wood dispersion affects home range size of female roe deer. Behavioural Processes 40:239-241.

Macchia F, Cavallaro V, Forte L, Terzi M. 2000. Vegetazione e clima della Puglia. Cahier Options Méditerranéennes 53:28-49.

Macdonald DW, Johnson PJ. 2008. Sex ratio variation and mixed pairs in roe deer: Evidence for control of sex allocation? Oecologia 158:361-370.

Mauget C, Mauget R, Sempéré A. 1997. Metabolic rate in female European roe deer (Capreolus capreolus): Incidence of reproduction. Canadian Journal of Zoology 75:731-739.

Melis C, Cagnacci F, Lovari S. 2005. Do male roe deer clump together during the rut? Acta Theriologica 50:253-262.

Minta SC. 1992. Tests of spatial and temporal interaction among animals. Ecological Applications 2:178-188.

Nilsen EB, Linnell JDC, Andersen R. 2004. Individual access to preferred habitat affects fitness components in female roe deer Capreolus capreolus. Journal of Animal Ecology 73:44-50.

Perco F. 1985. La situazione dei nuclei autoctoni di capriolo (Capreolus capreolus L., 1758) nella Calabria e nella Puglia. In: Atti del Convegno F.I.d.C. "Progetto Faunistico dell' Appennino", 1-2 February 1985. Pescara: Federazione Italiana della Caccia. pp. 152-161.

Perco F, Calò CM. 1994. The status of roe deer in Italy. In: Wotschikowsky U, editor. Proceedings of the 2nd European Roe Deer Meeting, 27-30 October 1994, Brixen. Ettal, Germany: Wildbiologische Gesellschaft München. pp. 43-53.
Randi E, Alves PC, Carranza J, Milošević-Zlatanović S, Sfougaris A, Mucci N. 2004. Phylogeography of roe deer (Capreolus capreolus) populations: The effects of historical genetic subdivisions and recent nonequilibrium dynamics. Molecular Ecology 13:3071-3083.

Rettie WJ, Messier F. 2001. Range use and movement rates of woodland caribou in Saskatchewan. Canadian Journal of Zoology 79:1933-1940.

Richard E, Morellet N, Cargnelutti B, Angibault JM, Vanpé C, Hewison AJM. 2008. Ranging behaviour and excursions of female roe deer during the rut. Behavioural Processes 79:28-35.

Sabine DL, Morrison SF, Whitlaw HA, Ballard WB, Forbes GJ, Bowman J. 2002. Migration behaviour of white-tailed deer under varying winter climate regimes in New Brunswick. Journal of Wildlife Management 66:718-728.

Saïd S, Gaillard JM, Duncan P, Guillon N, Guillon N, Servanty S, Pellerin M, Lefeuvre K, Martin C, Van Laere G. 2005. Ecological correlates of home-range size in spring-summer for female roe deer (Capreolus capreolus) in a deciduous woodland. Journal of Zoology 267:301-308.

Saïd S, Gaillard JM, Widmer O, Débias F, Bourgoin G, Delorme D, Roux C. 2009. What shapes intra-specific variation in home-range size? A case study of female roe deer. Oikos 118:1299-1306.

Said S, Servanty S. 2005. The influence of landscape structure on female roe deer home-range size. Landscape Ecology 20:1003-1012.

San José C, Lovari S. 1998. Ranging movements of female ore deer: Do home-loving does roam to mate? Ethology 104:721-728.

Sempéré AJ, Mauget R, Mauget C. 1998. Reproductive physiology of roe deer. In: Andersen R, Duncan P, Linnell JDC, editors. The European roe deer: The biology of success. Oslo, Norway: Scandinavian University Press. pp. 161-188.

Siegel S, Castellan NJ. 1998. Nonparametric statistics for the behavioural sciences. New York: McGraw-Hill.

Tassi F. 1969. Analisi ambientale naturalistica. In: Studio per un piano di sviluppo turistico del Comprensorio del Gargano e delle Isole Tremiti. Istituto Rilevazioni statistiche per conto Cassa Mezzogiorno, Roma. pp. 82-97.

Tufto J, Andersen R, Linnell J. 1996. Habitat use and ecological correlates of home range size in a small cervid: The roe deer. Journal of Animal Ecology 65:715-724.

Vincent JP, Bideau E, Hewison AJM, Angibault JM. 1995. The influence of increasing density on body weight, kid production, home range and winter grouping in roe deer (Capreolus capreolus). Journal of Zoology 236:371-382.

Walker LR, Boneta W. 1995. Plant and soil responses to fire on a fern-covered landslide in Puerto Rico. Journal of Tropical Ecology 11:473-479.

Worton BJ. 1989. Kernel methods for estimating the utilization distribution in home range studies. Ecology 70: $164-168$.

Wotschikowsky U, Schwab G. 1994. Das Rehproject Hahneaun. Aildbiologische Gesellschaft München e. V. Schlussbericht. 